Jerzy Bednarz, Ogólne spojrzenie na udział biegłych sądowych w procesach o stwierdzenie nieważności małżeństwa $w$ Sądzie Diecezjalnym $w$ Tarnowie w latach 1983-2015, [w:] Struktura i działalność Sądu Diecezjalnego w Tarnowie w latach 1983-2015, red. Robert Kantor, Kraków 2016, s. 41-53.

DOI: http://dx.doi.org/10.15633/9788374385299.04

KS. JERZY BEDNARZ

Uniwersytet Papieski Jana Pawła II w Krakowie

Wydział Teologiczny Sekcja w Tarnowie

\title{
Ogólne spojrzenie na udział biegłych sądowych w procesach o stwierdzenie nieważności małżeństwa w Sądzie Diecezjalnym w Tarnowie w latach 1983-2015
}

\section{Wprowadzenie na temat biegłego sądowego}

Sędzia kościelny w procesie kanonicznym o stwierdzenie nieważności małżeństwa powinien na podstawie dowodów, faktów i okoliczności osiągnąć stan pewności moralnej odnośnie do jego ważności lub nieważności. Jednym z dowodów, które pomagają sędziemu kościelnemu w zdobyciu takiego stanu pewności moralnej, jest opinia biegłego sądowego.

Według kanonistów ${ }^{1}$ aktualnie obowiązujące normy prawne o biegłym sądowym i sporządzanej przez niego opinii sądowo-psychologicznej są zawarte w Kodeksie prawa kanonicznego z 1983 roku $^{2}$ i instrukcji

1 Por. T. Rozkrut, Procesowy dialog sędziego z biegłym $w$ procesie małżeńskim ( $z$ przykładami $z$ orzecznictwa rotalnego, [w:] Zalety oraz wady kanonicznego procesu o stwierdzenie nieważnosci małżeństwa. Materiały $z$ ogólnopolskiego spotkania pracowników sądownictwa koscielnego w Gródku nad Dunajcem w dniach 13-14 czerwca 2011 roku. v Ogólnopolskie Forum Sądowe, red. T. Rozkrut, Tarnów 2012, s. 100-101.

2 O biegłym w procesie mówią następujące kanony KPK Z 1983 r. [dalej: KPK]: kan. 1447; $1455 \$ 3 ; 1574-1581 ; 1649 \$ 1$ n. 2; 1664; $1678 \$ 1 ; 168$ o. J. Zieliński, Indeks rzeczowy kodeksu prawa kanonicznego, Poznań 2006, s. 12. 
Dignitas connubii ${ }^{3}$. Duże znaczenie w tej materii mają także wypowiedzi papieży skierowane do Trybunału Roty Rzymskiej. ${ }^{4}$. Ponadto należy uwzględnić orzecznictwo Trybunału Apostolskiego Roty Rzymskiej ${ }^{5}$ oraz odpowiedź Najwyższego Trybunału Sygnatury apostolskiej z 1998 roku Quaesitum de usu periti in causis nullitatis matrimonii ${ }^{6}$. Istnieje także bogata literatura kanonistyczna o udziale biegłego psychologa w kanonicznym procesie o stwierdzenie nieważności małżeństwa ${ }^{7}$.

3 Instrukcja Dignitas connubii [dalej: DC], art. 46, \2, n. 15; 66, \$ 2; 75, § 1-3; 164; 165, $\S 1-2 ; 203, \S 1-2 ; 204, \S 1-2 ; 205, \S 1-2 ; 206 ; 207, \S 1-3 ; 208 ; 209, \S 1-2$, n. $1-3,3 ; 210, \S 1-2$; 211; 212, $\S_{1-2} ; 213, \S_{1-2}$, T. Rozkrut, Indeks alfabetyczny, [w:] Komentarz do Instrukcji procesowej „Dignitas connubii”, red. T. Rozkrut, Sandomierz 2007, s. 413.

4 Zbiór wypowiedzi papieży skierowanych do Roty Rzymskiej odnośnie do biegłych psychologów i ich opinii możemy znależć pod hasłem Pericias, [w:] A. Lizarraga Artola, Discursos Pontificios a la Rota Romana, Pamplona 2012, s. 221-222.

5 W tłumaczeniu na język polski: J. Góralski, Matrimonium facit consensus. Z orzecznictwa Trybunału Roty Rzymskiej w sprawach o nieważność małżeństwa rozpoznanych $z$ tytułów dotyczących zgody małżeńskiej (1991-2013), Płock 2014. Znajdujemy tu m.in. wypowiedź o dużym znaczeniu biegłego sądowego w procesie o stwierdzenie nieważności małżeństwa z kan. 1095, n. 3 KPK w wyroku c. Salvatori z 07.02.2013, por. J. Góralski, Matrimonium facit consensus..., dz. cyt., s. 180-189. Por. T. Rozkrut, Procesowy dialog sędziego $z$ biegłym $w$ procesie małżeńskim (z przykładami $z$ orzecznictwa rotalnego), [w:] Zalety oraz wady kanonicznego procesu o stwierdzenie nieważnosci małżeństwa..., dz. cyt., s. 99-129.

6 „Periodica” 87 (1998), s. 619-622.

7 Wśród publikacji naukowych możemy wymienić: K. E. Boccafola, Perito, [w:] Diccionario general de derecho canónico, red. J. Otaduy, A.Viana, J. Sedano, Pamplona, vol. 6, primera edición, diciembre 2012, s. 160-162; C. M. Morán Bustos, Pericias en las causas matrimioniales, [w:] Diccionario general..., vol. 6, dz. cyt., s. 152-16o; C. M. Morán Bustos, Prueba percial, [w:] Diccionario general..., vol. 6, dz. cyt., s. 635-638; Biegli, [w:] Kodeks Prawa Kanonicznego. Komentarz. Powszechne i partykularne ustawodawstwo Kościoła katolickiego. Podstawowe akty polskiego prawa wyznaniowego, red. P. Majer, Kraków 2011, s. 1182-1187; Biegli [w:] Komentarz do Instrukcji procesowej „Dignitas connubii”, dz. cyt., art. 203-213, s. 278-292; R. Sztychmiler, (Proces sporny) Eksperci, [w:] Komentarz do Kodeksu prawa kanonicznego. T. 5. Ks. 7, Procesy, red. J. Krukowski, Poznań 2007, s. 229-237; C. Peña García, La prueba pericial (arts. 203-213), [w:] C. M. Morán Bustos, C. Peña García, Nulidad de matrimonio y proceso canónico. Comentario adaptado a la Instrucción Dignitas connubii, Madrid 2007, s. 346-362; F. Gil de las Heras, Los peritos, [w:] Procesos de nulidad matrimonial. La instrucción Dignitas connubii. Actas del XXIV Curso de Actualización en Derecho Canónico de la Facultad de derecho Canónico (Pamplona, 24-26 octubre de 2005), red. R. Rodríguez-Ocaña, J. Sedano, Pamplona, segunda edición: Agosto 2007, s. 224-228; T. Rozkrut, Walor opinii Biegłego w kanonicznym procesie matżeńskim (studium historyczno-prawne), Tarnów 2002. 
Prawo kanoniczne pozwala na skorzystanie z pomocy biegłego zawsze, ilekroć jego wiedza i rzetelność pomogą w udowodnieniu faktu lub poznaniu faktycznego stanu rzeczy ${ }^{8}$.

Kodeks prawa kanonicznego ${ }^{9}$, instrukcja Dignitas connubi $i^{10}$ oraz motu proprio Mitis Iudex Dominus Iesus ${ }^{11}$ wskazują na powinność skorzystania z opinii biegłego lub kilku biegłych w sprawach impotencji lub wady zgody małżeńskiej spowodowanej chorobą umysłową lub niezdolnością, o której mówi kan. $1095 \mathrm{KPK}^{12}$. Od tej zasady Sędzia może odstąpić, jeżeli $\mathrm{z}$ akt sprawy jasno wynika, że opinia biegłego jest wyraźnie niepotrzebna. W aktach sprawy może bowiem już wcześniej znajdować się np. wystarczająca dokumentacja medyczna lub rzeczowe opinie biegłych, którzy występowali $\mathrm{w}$ tej samej sprawie lub $\mathrm{w}$ innej sprawie, ale między tymi samymi stronami ${ }^{13}$.

\section{I.I. Mianowanie biegłego sądowego}

Sędzia mianuje biegłego dekretem do konkretnej sprawy przy zachowaniu określonych prawem warunków ${ }^{14}$ : po wysłuchaniu stron, a w sprawach publicznych także po wysłuchaniu rzecznika sprawiedliwości lub obrońcy węzła albo na wniosek stron.

Powołując do danej sprawy biegłego sądowego, należy wziąć pod uwagę jego kwalifikacje. Biegły powinien się odznaczać bardzo dobrą znajomością materii popartą doświadczeniem (np. w medycynie, psychologii, seksuologii). Nie bez znaczenia jest, aby miał ukończone studia wyższe i podjął dalsze studia specjalistyczne. Biegły powinien cieszyć się uczciwością i właściwą postawą religijno-moralną. Ma znać nauczanie Kościoła na temat małżeństwa i jego przymiotów, a antropologia chrześcijańska ma być fundamentem przy wydawaniu przez niego opinii

Por. KPK, kan. 1574.

9 Por. KPK, kan. 168 o.

${ }^{10}$ Por. DC, art. $203 \$ 1-2$.

${ }_{11}$ Papież Franciszek, List apostolski Mitis Iudex Dominus Iesus, 15.08.2015, kan. $1678 \S 3$.

${ }_{12}$ Por. J. Sokołowski, Sprawy o stwierdzenie nieważności małżeństwa $z$ udziałem biegłych, [w:] „Prawo Kanoniczne” 56 (2013) nr 4, s. 101-115.

${ }^{13}$ Por. Komentarz do Instrukcji procesowej „Dignitas connubii”, dz. cyt., s. 279; por. Kodeks prawa kanonicznego..., dz. cyt., s. 1183.

${ }^{14}$ Por. кРк, kan. 1575, por. Kodeks prawa kanonicznego..., dz. cyt., s. 1183. 
sądowo-psychologicznej ${ }^{15}$. Biegły sądowy zatem ,jest osobą powołaną przez organ sądowy do udziału w procesie ze względu na swe szczególne kwalifikacje w dziedzinie psychiatrii lub psychologii, celem dostarczenia sędziemu konkretnych ustaleń i ocen stanu psychicznego kontrahenta w chwili zawierania małżeństwa, dokonanych według specyficznej metody naukowej oraz reguł profesjonalnych, a którego właściwe rozeznanie przekracza kompetencje specjalistyczne sędziego" ${ }^{16}$.

Oprócz sędziego również same strony mogą sobie wyznaczyć tzw. biegłych prywatnych, którzy jednak potrzebują zatwierdzenia przez sędziego $^{17}$. Biegli ci za zezwoleniem sędziego mogą przejrzeć akta sprawy oraz być obecni przy wykonywaniu ekspertyzy. Zawsze mogą przedstawić własną relację ${ }^{18}$.

Według aktualnej praktyki w pierwszej instancji powołuje się jednego biegłego i kolejno po jednym w następnych instancjach ${ }^{19}$. Prawo daje jednak sędziemu możliwość, w zależności od trudności sprawy, mianowania kilku biegłych. W takiej sytuacji każdy biegły sporządza własną opinię, chyba że sędzia poleci sporządzić jedną relację, ze szczegółowym odnotowaniem różnicy zdań, jeśli takowa zachodzi ${ }^{20}$.

$\mathrm{W}$ razie konieczności istnieje możliwość powołania tzw. superbiegłego (peritior), który musi pod względem kwalifikacji zawodowych i naukowych przewyższać biegłych wcześniej obecnych w procesie. Jest

15 Por. DC, art. 205, por. Komentarz do instrukcji procesowej „Dignitas connubii”, dz. cyt., s. $281-282$.

${ }^{16}$ Ta definicja dziekana Roty Rzymskiej ks. bp. prof. Antoniego Stankiewicza została przedstawiona w czasie Międzynarodowego Sympozjum dla pracowników Sądów Kościelnych w Europie Środkowo-Wschodniej, które miało miejsce w Lublinie w dniach 19-21 września 1991 roku. Por. J. Sokołowski, Sprawy o stwierdzenie nieważności małżeństwa..., dz. cyt., s. 104. Według ks. prof. R. Sztychmilera biegłym w rozumieniu procesowym jest „rzeczoznawca (nazywany też specjalistą lub ekspertem), posiadający fachowe kwalifikacje nabyte przez specjalistyczne studia lub wieloletnie doświadczenie (jeszcze lepiej, gdy kwalifikacje wynikają z obu wymienionych źródeł), który z polecenia sędziego wydaje dla potrzeb sądowych opinię dotyczącą ustalenia jakiegoś istotnego dla procesu a wątpliwego faktu lub poznania prawdziwej natury jakiejś rzeczy". R. Sztychmiler, Ochrona praw człowieka w normach kanonicznego procesu spornego, Olsztyn 2003, s. 186.

${ }_{17}$ Por. KPK, kan. $1581 \S 1$.

${ }_{18}$ Por. KPK, kan. $1581 \S 2$.

19 Por. T. Rozkrut, Dialog sędziego z biegłym w kanonicznym procesie małżeńskim, „Prawo Kanoniczne" 54 (2011) nr 1-2, s. 166-167.

${ }^{20}$ Por. KPK, kan. 1578. 
on bowiem recenzentem dla wcześniej sporządzonych opinii. Opinia wydana przez superbiegłego jest ostateczna i rozstrzygająca pod względem naukowym „kontrowersyjny problem procesowy”"

Biegli zeznają w sądzie na sposób tzw. świadka technicznego ${ }^{22}$. Sędzia ma zatem możliwość wykluczenia biegłego z procesu $\mathrm{z}$ tych samych przyczyn, co wykluczenia świadka ${ }^{23}$. "Za niezdolnych do pełnienia funkcji biegłego uznaje się tych, którzy są niezdolni do składania zeznań, związani bliskim pokrewieństwem z którąś ze stron oraz tych, którzy poza procesem sporządzili opinię na prośbę którejś ze stron. Niezdatnymi są ci, którzy nie mają kompetencji w specjalności, jakiej wymaga dany przypadek, a także osoby, których złe prowadzenie się lub poglądy sprzeczne z wiarą odbierają wiarygodność potrzebną do sporządzenia opinii. Wśród słusznych przyczyn wyłączenia są m.in. bliska zażyłość z którąś ze stron lub publicznie okazywana nieprzyjaźń wobec którejś strony"24.

I.2. Wpływ opinii biegłego sądowego na proces kościelny odnośnie nieważności małżeństwa

W dekrecie zlecającym biegłemu sądowemu wykonanie opinii w danej sprawie małżeńskiej sędzia powinien jasno wskazać pytania, na które oczekuje precyzyjnej odpowiedzi. Dekret powinien m.in. wskazywać, czy biegły ma udzielić odpowiedzi wyłącznie na podstawie akt sprawy, czy też w oparciu o badanie psychologiczne strony lub stron. Biegłemu należy przesłać akta sprawy oraz inne dokumenty i pomoce, które są mu potrzebne do jak najlepszego wykonania powierzonego zadania. Ponadto dekret winień wskazywać termin przygotowania i przedstawienia opinii ${ }^{25}$.

Większość spraw o stwierdzenie nieważności małżeństwa prowadzonych jest $\mathrm{z}$ tytułu niezdolności natury psychicznej (kan. $1095 \mathrm{KPK}$ ). W tym przypadku sędzia ma zapytać biegłego psychologa o istnienie w okresie

\footnotetext{
${ }^{21}$ Por. Komentarz do instrukcji procesowej „Dignitas connubii”, dz. cyt., s. 289-29o.

${ }^{22}$ Por. Kodeks prawa kanonicznego..., dz. cyt., s. 1183.

${ }^{23}$ Por. KPK, kan. 1550, 1555.

${ }^{24}$ Por. Kodeks prawa kanonicznego..., dz. cyt., s. 1183.

${ }_{25}$ Por. KPK, kan. 1577, Komentarz do instrukcji procesowej „Dignitas connubii”, dz. cyt., S. $283-284$.
} 
zawierania małżeństwa konkretnej anomalii. Biegły ma określić jej charakter (trwały lub przejściowy), jej natężenie, kiedy i z jakiej przyczyny oraz w jakich okolicznościach powstała i co wskazywało na jej istnienie ${ }^{26}$. Instrukcja Dignitas connubii w art. $209 \$ 2$ wprost precyzuje, co powinno być przedmiotem opinii biegłego, gdy chodzi o małżeństwo zaskarżone z tytułu kan. 1095 KPK. W sprawach z tytułu braku używania rozumu należy pytać, „,zy anomalia poważnie zakłócała używanie rozumu w czasie zawierania małżeństwa; z jaką intensywnością i jak się przedstawiała; $2^{\circ} \mathrm{W}$ sprawach $\mathrm{z}$ tytułu braku osądu krytycznego należy pytać, jaki był wpływ anomalii na zdolność krytyczną oraz na możliwość swobodnego decydowania w przedmiocie poważnych decyzji, w szczególności w wolnym wyborze stanu życia; $3^{\circ} \mathrm{W}$ sprawach zaś dotyczących niezdolności podjęcia istotnych obowiązków małżeńskich należy pytać, jakie były natura oraz ciężkość przyczyny psychicznej, z powodu której strona nie tylko ma poważną trudność, ale również niemożliwość realizowania zadań związanych z obowiązkami małżeńskimi”"27.

Biegły ma odpowiedzieć na powyższe pytania i sformułować odpowiednie wnioski na potrzeby procesu według wskazanej przez niego techniki i zdobytej wiedzy. Opinia ma opierać się na zasadach naukowych i być opracowana według metod naukowych. Biegły sądowy winien odpowiedzieć precyzyjnie na pytanie, czy występujące zaburzenia czy nieprawidłowości osobowościowe były na tyle poważne w chwili zawierania małżeństwa, że uniemożliwiły powstanie i zwykłe funkcjonowanie wspólnoty małżeńskiej, czy jedynie utrudniały budowanie wspólnoty małżeńskiej. Biegły nie może przekraczać swoich kompetencji i wypowiadać się na temat ważności czy nieważności danego małżeństwa, co należy tylko do kompetencji sędziego kościelnego ${ }^{28}$.

${ }^{26}$ DC, art. 209, $\$ 1$. Wzmianki o potrzebie i znaczeniu opinii biegłego psychologa w sprawach o stwierdzenie nieważnosci małżenstwa $\mathrm{z}$ kan. 1095 KPK znajdujemy m.in. w artykule Dziekana Trybunału Roty Nucjatury Apostolskiej w Madrycie. Zob. C. Moran, La prueba de las anomalías graves del canon 1095, [w:] La formación de la voluntad matrimonial: anomalías, patologías y normalidad. Actas del x Simposio Internacional del Instituto Martín de Azpilcueta (Pamplona noviembre de 2012), red. J. I. Bañares, J. Bosch, Eunsa, primera edición: marzo 2014, s. 147-203.

${ }^{27}$ DC, art. 209, \$2.

${ }^{28}$ Por. DC, art. 209, \$3. Zob. J. T. Martín de Agar, La pericia super actis: dificultades, certeza y valor objetivo, [w:] La formación de la voluntad matrimonial..., dz. cyt., s. 307-322. 
W opiniach sądowo-psychologicznych spotyka się przeważnie następujące przejawy zaburzeń: „niedojrzałość emocjonalna i społeczna; dysharmonia osobowości rozumiana jako niekontrolowana zmienność nastrojów, niespójność w ocenach i sądach, zaburzenia sfery wolicjonalnej; cechy degradacji osobowościowej wskutek uzależnienia od alkoholu; charakteropatia pourazowa (udokumentowana klinicznie) obniżająca funkcje psychiczne wskutek organicznego uszkodzenia w obrębie centralnego układu nerwowego; psychiczne uwarunkowania istotnych zaburzeń w sferze aktywności seksualnej”29.

"Znawcy zagadnienia jednoznacznie podkreślają, że w metodologii pracy psychologa najistotniejsza jest rozmowa ze stroną, a potem dopiero kwestionariusze i testy. Naturalnie wszystkie te wyniki należy osadzić w tym, co już zostało uwidocznione w aktach sprawy, jak również $\mathrm{w}$ środowisku życia uczestnika procesu. Natomiast sama opinia biegłego psychologa winna odznaczać się jednoznacznością i zwięzłością, tzn. powinna stwierdzać, czy mamy do czynienia z rzeczywistą patologią i czy ma ona charakter absolutny, czy też względny (ta ostatnia występuje wtedy, gdy osoba poprawnie funkcjonuje w środowisku pozamałżeńskim, lecz w samym pożyciu małżonków wykazuje cechy wyraźnej niedojrzałości psychicznej)"30.

Należy zauważyć, że biegły psycholog w sprawach o stwierdzenie nieważności małżeństwa wchodzi ze stronami procesowymi w pewne specyficzne relacje, które wymagają z jego strony zachowania

${ }^{29}$ W. Krupa, Zasady opracowania opinii biegłego psychologa w sprawach o nieważność małżeństwa, „Ius Matrimoniale” 1 (1996), s. 139. Szerokie omówienie różnych zaburzonych osobowości znajdujemy m.in. w: S. Paździor, Przyczyny psychiczne niezdolności osoby do zawarcia małżeństwa $w$ świetle kan. 1095, Lublin 1999; S. Paździor, Przyczyny poważnego braku rozeznania oceniającego w świetle kan. 1095 n. 2, Lublin 2004; W. Srebro, Aktywność i procesowy dialog biegłego z zakresu psychologii z sędzia w procesie małżeńskim, [w:] Zalety oraz wady kanonicznego procesu o stwierdzenie nieważnosci małżeństwa..., dz. cyt., s. 131-142. Na uwagę zasługuje referat biegłego psychologa Trybunału Roty Nuncjatury Apostolskiej w Madrycie odnośnie do różnych typów osobowości. Zob. C. de Cendra, La pericia super actis: dimensión psiquiátrica, [w:] La formación de la voluntad matrimonial..., dz. cyt., s. 291-306.

${ }^{30} \mathrm{R}$. Wierzchanowski, Biegły sądowy w kanonicznym procesie małżeńskim. Sposób powołania biegłego, zasady redakcji opinii i jej wpływ na sprawę, http://www.opoka.org.pl/ biblioteka/T/TA/TAI/rw_biegly-sadowy.html\# (29.06.2015). 
zasad etyczno-zawodowych ${ }^{31}$. „Z punktu widzenia etyczno-zawodowego na uznanie zasługują takie postawy badawcze, jak: postawa zrównoważona, adekwatna, dyskretna, realistyczno-optymistyczna, empatyczna oraz postawa pokory. Tego rodzaju postawy pozwalają w sposób zadowalający podejmować zadania przez biegłego psychologa w spawach nieważności małżeństwa"32.

Mówiąc o roli biegłego w procesie kanonicznym o stwierdzenie nieważności małżeństwa, trzeba zauważyć, że w wielu przypadkach jest on pomocny, a w niektórych wręcz konieczny. Biegły występuje w procesie jako ekspert de arte et de scientia ${ }^{33}$. Mimo że jego opinia często ma istotny wpływ na wynik sprawy, to jednak tym, który decyduje, czy opinię należy przyjąć, czy odrzucić, jest sędzia jako peritus peritorum ${ }^{34}$. Sędzia nie może przyjmować opinii biegłego lub biegłych bezkrytycznie, ale powinien gruntownie rozpatrzyć argumenty i ich wnioski wraz z pozostałymi dowodami i okolicznościami sprawy ${ }^{35}$. Opinia biegłego odgrywa w procesie jedynie funkcję pomocniczą, istotnie różną od decyzji sędziego, który jako jedyny orzeka w obliczu Kościoła o ważności bądź nieważności zaskarżonego małżeństwa ${ }^{36}$. „Niemniej jednak duża kompetencja zawodowa biegłego oraz jego uczciwość są gwarantem waloru procesowego tego dość specyficznego dowodu procesowego, który jednocześnie powinien mieć duży wkład dla wiarygodnego administrowania sprawiedliwości przez Kościół we współczesnym świecie”37.

${ }_{31}$ Zob. M. Stepulak, Specyfika relacji psycholog-strony procesowe $w$ sprawach dotyczacych stwierdzenia nieważności małżeństwa, [w:] Kościelne prawo procesowe. Materialy i studia, red. A. Dzięga, M. Wróbel, Lublin 2003, s. 259-288 (Kościelne Prawo Procesowe, 3).

${ }_{32}$ M. Stepulak, Typy postaw badawczych biegłego psychologa $w$ sprawach dotyczacych nieważności matżeństwa, [w:] Prawo rodzinne, red. A. Dzięga, M. Greszata, P. Telusiewicz, Lublin 2007, s. 409 (Kościelne Prawo Procesowe. Materiały i Studia, 4).

${ }_{33}$ T. Rozkrut, Rola biegłego w procesach małżeńskich, „Prawo Kanoniczne” 41 (1998) nr 1-2, s. 260.

${ }^{34}$ Por. КРк, kan. 1579. Por. T. Rozkrut, Dialog sędziego z biegłym..., dz. cyt., s. 174.

35 Por. R. Sztychmiler, Ochrona praw człowieka $w$ normach kanonicznego procesu spornego, dz. cyt., s. 192.

${ }^{36} \mathrm{R}$. Wierzchanowski, Biegły sądowy w kanonicznym procesie małżeńskim. Sposób powołania biegłego, zasady redakcji opinii $i$ jej wplyw na sprawę, http://www.opoka.org.pl/ biblioteka/T/TA/TAI/rw_biegly-sadowy.html\# (29.06.2015).

${ }^{37}$ T. Rozkrut, Dialog sędziego z biegtym..., dz. cyt., s. 174. 


\section{Biegli sądowi w Sądzie Diecezjalnym w Tarnowie w latach $1983-2015^{38}$}

Po ogólnym wprowadzeniu o aktualnie obowiązujących normach prawnych dotyczących biegłych sądowych przejdziemy do bardziej szczegółowego omówienia biegłych pracujących w tarnowskim Sądzie Diecezjalnym w latach 1983-2015.

\section{I. Dane o biegłych sądowych}

\section{I.I. BIEGLI Z ZAKRESU MEDYCYNY (ZWŁASZCZA PSYCHIATRII I GINEKOLOGII)}

- dr Marian Ciećkiewicz (Kraków),

- dr Andrzej Kowal (Kraków),

- lek. med. dr Stanisław Kołakowski (Kraków),

- lek med. Marek Juryk (Bochnia),

- lek. med. K. Zięba,

- lek. med. Joanna Walawska,

- prof. dr hab. n. med. Rudolf Klimek (Kraków, Instytut Ginekologii),

- lek. med. Ewa Chrapusta-Witek,

- lek. med. Dariusz Asztabski (pracuje aktualnie).

Ponadto Trybunał korzystał z opinii innych biegłych z zakresu medycyny powoływanych ad casum lub tych, których prywatne opinie były uznawane przez Trybunał za niepotrzebujące weryfikacji.

\section{I.2. BIEGLI Z ZAKRESU PSYCHOLOGII}

- mgr Irena Gancarz,

- mgr Urszula Seliga,

- mgr Ewa Rzędkowska (pracuje aktualnie),

- mgr Jacek Skrobot,

- mgr Małgorzata Kula (Dębica),

- mgr Maria Ciesielska,

- mgr Krystyna Zając (Nowy Sącz),

${ }^{38}$ Odnośnie do biegłych sądowych pracujących w Sądzie Diecezjalnym w Tarnowie wykorzystano dane akt sądowych zabrane przez mgr. lic. Jakuba Fenrycha - adwokata stałego w tym sądzie. 
- dr Wacław Srebro (pracuje aktualnie),

- mgr Elżbieta Wardzała-Gogola (pracuje aktualnie),

- mgr Witold Masiak (Nowy Sącz),

- mgr Ewa Faliszek-Podgórska,

- mgr Maria Gąsiorowska,

- mgr Beata Leśniak,

- dr Renata Smoleń (pracuje aktualnie),

- mgr Anna Lublińska (Ukraina),

- mgr Marcin Kapturkiewicz (pracuje aktualnie),

- mgr Zofia Wojtanowska (pracuje aktualnie),

- mgr Maria Gałek (pracuje aktualnie),

- mgr Lucyna Bogacz (pracuje aktualnie),

Trybunał korzystał także z opinii innych biegłych z zakresu psychologii klinicznej, psychologii osobowości czy specjalistów w zakresie seksuologii.

W ramach procesu kanonicznego wykorzystywane były również opinie psychologiczne i psychiatryczne sporządzane do postępowań świeckich (np. rozwodowych czy karnych) których autorami byli biegli z list przy Sądzie Okręgowym w Tarnowie, Nowym Sączu, Rzeszowie czy Tarnobrzegu, albowiem teren Diecezji Tarnowskiej obejmował w całości bądź częściowo obszar właściwości tych sądów.

2.2. Udział biegłych sądowych w procesach małżeńskich w Sądzie Diecezjalnym w Tarnowie w latach I983-20 I5

Poniższa tabela przestawia udział biegłych w procesach małżeńskich w Sądzie Diecezjalnym w Tarnowie:

Tabela 1. Udział biegłych w procesach małżeńskich

\begin{tabular}{|c|c|c|c|c|}
\hline $\begin{array}{l}\text { ROK } \\
\text { PRZYJĘCIA } \\
\text { SPRAWY }\end{array}$ & $\begin{array}{l}\text { LICZBA SPRAW } \\
\text { PRZYJĘTYCH }\end{array}$ & $\begin{array}{c}\text { UDZIAE BIEGEYCH } \\
\text { Z ZAKRESU } \\
\text { PSYCHOLOGII }\end{array}$ & $\begin{array}{l}\text { UDZIAE BIEGEYCH Z ZA- } \\
\text { KRESU MEDYCYNY }\end{array}$ & $\begin{array}{l}\text { UDZIAE } \\
\text { BIEGŁYCH } \\
\text { OGÓŁEM }\end{array}$ \\
\hline 1983 & 67 & 2 & 11 & 13 \\
\hline 1984 & 71 & 8 & 9 & 17 \\
\hline 1985 & 45 & 8 & 11 & 19 \\
\hline
\end{tabular}


Ogólne spojrzenie na udział biegłych sądowych w procesach...

\begin{tabular}{|c|c|c|c|c|}
\hline $\begin{array}{l}\text { ROK } \\
\text { PRZYJĘCIA } \\
\text { SPRAWY }\end{array}$ & $\begin{array}{l}\text { LICZBA SPRAW } \\
\text { PRZYJĘTYCH }\end{array}$ & $\begin{array}{c}\text { UDZIA BIEGLYCH } \\
\text { Z ZAKRESU } \\
\text { PSYCHOLOGII }\end{array}$ & $\begin{array}{c}\text { UDZIAE BIEG } \mathrm{AYCH} \\
\text { Z ZAKRESU MEDYCYNY }\end{array}$ & $\begin{array}{c}\text { UDZIAE } \\
\text { BIEGŁYCH } \\
\text { OGÓŁEM }\end{array}$ \\
\hline 1986 & 56 & 16 & 7 & 23 \\
\hline 1987 & 58 & 18 & 5 & 23 \\
\hline 1988 & 80 & 35 & 11 & 46 \\
\hline 1989 & 65 & 37 & 9 & 46 \\
\hline 1990 & 87 & 34 & 10 & 44 \\
\hline 1991 & 84 & 52 & 5 & 57 \\
\hline 1992 & 77 & 55 & 5 & 60 \\
\hline 1993 & 57 & 41 & 4 & 45 \\
\hline 1994 & 82 & 71 & 1 & 72 \\
\hline 1995 & 86 & 69 & 4 & 73 \\
\hline 1996 & 65 & 53 & 1 & 54 \\
\hline 1997 & 90 & 73 & 1 & 74 \\
\hline 1998 & 101 & 77 & 2 & 79 \\
\hline 1999 & 100 & 80 & 2 & 82 \\
\hline 2000 & 133 & 111 & 2 & 113 \\
\hline 2001 & 111 & 97 & 2 & 99 \\
\hline 2002 & 103 & 84 & o & 84 \\
\hline 2003 & 102 & 86 & 1 & 87 \\
\hline 2004 & 100 & 93 & 0 & 93 \\
\hline 2005 & 111 & 104 & 1 & 105 \\
\hline 2006 & 112 & 105 & 0 & 105 \\
\hline 2007 & 116 & 97 & 2 & 99 \\
\hline 2008 & 129 & 116 & 1 & 117 \\
\hline 2009 & 106 & 95 & 1 & 96 \\
\hline 2010 & 91 & 84 & 1 & 85 \\
\hline 2011 & 106 & 96 & 0 & 96 \\
\hline
\end{tabular}


W poniższym wykresie kolorem zielonym oznaczono procesy bez udziału biegłego, czerwonym kolorem procesy z udziałem biegłych z zakresu medycyny, zaś niebieskim biegłych z zakresu psychologii.

Wykres 1. Udział biegłych zatwierdzonych w Sądzie Diecezjalnym w Tarnowie w procesach małżeńskich. Analiza wykresu.

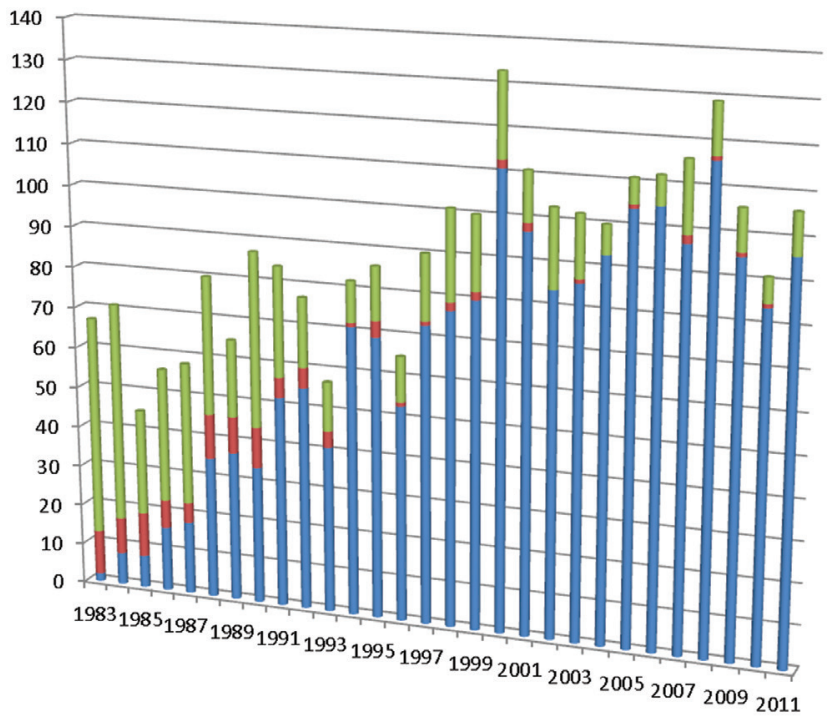

W ramach analizy udziału biegłych trybunału w stosunku do spraw przyjętych w danym roku kalendarzowym należy zauważyć w pierwszej kolejności zwiększenie udziału biegłych w postępowaniach (w ogóle) od min. 19,4 proc. w 1983 roku do maks. 94,6 proc. w 2005 roku. W ostatnich 10 latach (w których wszystkie sprawy zakończyły etap procesowy skierowania do biegłego, tj. 2001-2011) udział biegłego wyniósł od 65 do 80 proc.

Jak kształtuje się udział biegłych z zakresu psychologii w stosunku do biegłych z zakresu różnych dziedzin medycyny? $\mathrm{W}$ badanym okresie (tj. w latach 1983-2015) w sprawach małżeńskich maksymalny udział biegłych z zakresu medycyny to 85 proc. w stosunku do biegłych z zakresu psychologii - 15 proc. (w 1983 roku) do sytuacji, w której biegli z zakresu psychologii stanowili 100 proc. (w przypadku spraw przyjętych w 2002, 2004, 2006, 2011 roku). Wydaje się, że przyczynę wzrostu 
znaczenia biegłych z zakresu psychologii w procesach kanonicznych należy upatrywać w znacznym rozwoju tychże badań i na ich podstawie lepszego wytłumaczenia anomalii osobowościowych mogących mieć znaczenie zwłaszcza dla ważności konsensu małżeńskiego. Bardzo często diagnozowane są poważne zaburzenia osobowości, które uniemożliwiają podjęcie istotnych obowiązków małżeńskich i rodzinnych, które jednak nie są wskazaniami do leczenia psychiatrycznego.

Wśród biegłych z zakresu medycyny szczególną uwagę należy zwrócić na biegłych z zakresu psychiatrii oraz biegłych z zakresu ginekologii. Opinie pierwszych $\mathrm{z}$ nich to diagnozy chorób psychicznych uniemożliwiających podjęcie obowiązków małżeńskich i rodzinnych, opinie tych drugich to głównie opinie dotyczące fizycznej niemożliwości odbycia stosunku małżeńskiego (impotencji) lub potwierdzenie faktu niedopełnienia małżeństwa.

\section{Uwagi końcowe}

Dane za ostatnie lata (2012-2015) pracy Trybunału Diecezjalnego w Tarnowie w kontekście udziału biegłych w sprawach małżeńskich nie zostały przedstawione powyżej w tabeli i wykresie ze względu na fakt, iż nie wszystkie sprawy przyjęte przez sąd zostały już doprowadzone do etapu decyzji sędziowskiej o powołaniu lub niepowoływaniu biegłego. I tak:

- w sprawach przyjętych w 2012 roku na 120 spraw przyjętych w 111 powołano biegłych z zakresu psychologii, nie powołano biegłych z zakresu medycyny, w 6 sprawach nie powoływano biegłych, zaś 3 sprawy nie doszły do tego etapu;

- w sprawach przyjętych w 2013 roku na 141 spraw przyjętych do obecnej chwili w 81 powołano biegłych z zakresu psychologii, w 5 sprawach podjęto decyzje o niepowoływaniu biegłego, nie powołano biegłych z zakresu medycyny, ale 55 spraw nie doszło do tego etapu;

- w sprawach przyjętych w 2014 roku na 176 spraw przyjętych w 2 podjęto decyzję o niepowoływaniu biegłego, dopiero w 8 sprawach powołano biegłych psychologów, ale 166 spraw nie doszło do tego etapu;

- na 129 spraw przejętych w 2015 roku (do 9.09.2015) żadna ze spraw nie doszła jeszcze do etapu podejmowania decyzji o powołaniu biegłego, a znaczna cześć spraw nie została jeszcze przyjęta do przewodu sądowego. 